\title{
PERSPEKTIF WESLEYAN-ARMINIAN TERHADAP KONSEP DIKUDUSKAN KARENA POSISI DAN IMPLEMENTASINYA DALAM KEHIDUPAN ORANG PERCAYA
}

\author{
Oleh: Yupiter Hulu ${ }^{1}$
}

\begin{abstract}
In the mid of the world bustle, civilization and technology development, many Christian are ignoring the Biblical holiness standards. Apparently, enthusiasm in discussing, learning and understanding about holiness values and standards is very less. Some people think that it is too hard to be achieved and experienced. God calls His people to be a holy and pleasing in His sight. In New Testament Understanding when God calls His people, He will not let them walk alone. The works of God through the Holy Spirit will help and equip believers to live their life. Through the gift of the Holy Spirit, believers equipped and given a new "position" that might believers grow in it and please God through their new identity.
\end{abstract}

Key words : Sanctification, positional, initial, wesleyan, Arminian

\section{Pendahuluan}

Ketika Allah memanggil orang percaya sebagai umat pilihan dan umat yang kudus dan kepunyaan Allah (Kel. 19:6 ; I Ptr. 2:9, 1:6 ; Im. 11:14 ; Rm. 12:1), dan lagi tanpa kekudusan seseorang tidak bisa melihat Allah (Ibr. 12:14). Karena itu orang percaya harus meresponi dan menggenapi panggilan tersebut dalam kehidupannya. Untuk menjadi umat kudus tentu bukan hal yang mudah, berbagai tantangan dan godaan yang dihadapi dalam hidup ini serta rela untuk menyalibkan diri untuk hal-hal duniawi. Sehingga berbicara tentang kekudusan, banyak orang percaya pada masa kini yang sudah patah semangatnya dan tidak tertarik membahasnya, merasa diri tidak mampu dan tidak layak. Karena nilainilai kekudusan dinilai sebagai sesuatu yang berstandar tinggi, sangat beratdan manusia tidak bisa berbuat apa-apa atau tidak mampu mencapainya.

Melalui artikel ini penulis akan memberikan gagasan-gagasan dan pemaparan tentang satu bagian yang berhubungan dengan hal ini di dalam ajaran teologi WesleyanArminian, yaitu tentang 'kekudusan'. Melalui tema ini penulis akan menjelaskan bagaimana konsep kekudusan, menggali maknanya dan menjadikannya sebagai implementasi dalam kehidupan orang percaya. Sehingga dapat memberikan dorongan dan membangkitkan semangat orang percaya untuk terus setia dan berusaha mencari perkenaan Tuhan dan menjadi orang percaya yang kudus. Karena penulis yakin bahwa ketika Allah memanggil umatNya sebagai umat yang kudus, orang percaya tidak berjalan sendiri. Allah melalui peran dan kuasa Roh Kudus menolong, menyertai dan memperlengkapi orang percaya dalam perjalanan hidupnya (mat. 28:20; Rm. 8:28).

1 Yupiter Hulu adalah pengajar di STT Nazarene Indonesia Yogyakarta. Ia menyelesaikan pendidikan program Sarjana Teologi dan Magister Teologi di STT Nazarene Yogyakarta dan melayani di bidang administrasi STTNI. 


\section{Gambaran umum tentang konsep kekudusan dalam ajaran Wesleyan-Arminian}

Sebelum penulis memberikan penjelasan tentang konsep kekudusan, terlebih dahulu perlu dimengerti arti dari kata kudus itu sendiri. Istilah kudus dalam kamus bahasa Indonesia mempunyai arti suci dan murni. ${ }^{2}$ Kata ini dalam bahasa Yunani menggunakan kata 'hagios' dari akar kata 'hag' yang artinya dibebaskan dari kuasa dosa dan dilepaskan dari hukuman maut. Dalam bahasa Inggris kata 'kudus' atau 'kekudusan' berasal dari akar kata Anglo Saxon. Bentuk bahasa Inggris kuno untuk 'kudus' adalah haliq, dari akar kata hal yang berarti utuh, satu akar kata dengan 'sehat, menyembuhkan, kesehatan dan menyucikan.' Kekudusan adalah suatu keadaan atau kondisi kudus, utuh, disembuhkan. ${ }^{3}$

Istilah yang sama dengan kekudusan adalah kesucian, yang dipakai sinonim dengan beberapa terjemahan Alkitab bahasa Inggris. Kata kesucian ini beserta bentukbentuk yang berkaitan, 'menyucikan' dan 'disucikan' berasal dari akar kata bahasa Norman-latin. Kata latin 'sanctifio'berasal dari kata 'sanctus'yang artinya suci atau dipisahkan untuk pelayanan kepada para dewa, dan facio artinya membuat. Menyucikan berarti membuat suci atau keramat, dipisahkan untuk hal-hal agamis dan suci. Menyucikan berarti menyucikan dari dosa; membuat tata cara kesucian. Sanctus juga adalah akar kata 'orang suci,' satu istilah yang diterapkan pada semua umat Allah dalam Perjanjian Baru. ${ }^{4}$

Setiap orang percaya didorong untuk memperoleh pengalaman pengudusan. Karena tanpa kehidupan yang kudus, seorang tidak bisa melihat Allah (Ibr. 12:14). Paulus dalam suratnya kepada jemaat Roma, supaya mempersembahkan tubuh sebagai persembahan yang kudus. Hanya yang kudus yang layak diterima oleh Tuhan (Rm. 12:1). Paulus menasehati jemaat di Efesus supaya hidup kudus dan tak bercacat di hadapan-Nya (Ef. 1:4). Rasul Petrus dalam suratnya menasehatkan hendaklah kamu kudus, sama seperti Dia yang kudus (I Ptr. 1:15). Selanjutnya Rasul Petrus menyampaikan perkataan Tuhan : "Kuduslah kamu sebab Aku kudus..(I Ptr. 1:16)."

Kekudusan adalah standar kehidupan rohani orang percaya di hadapan Tuhan. Firman Tuhan dalam Ibrani 12:14a, "kejarlah kekudusan..." Orang percaya harus berlomba-lomba untuk mengalami pengudusan. Kata 'kejarlah' berarti sesuatu yang didapatkan dengan tidak mudah, sama seperti seseorang yang mengikuti lomba lari. Dia harus berusaha sekuat tenaga dan dengan strategi yang dapat dilakukan. Demikian juga gambaran orang percaya dalam menjalani hidup. Banyak tantangan dan godaan yang dihadapi yang datangnya dari iblis. Musuh orang percaya adalah iblis yang berusaha menjatuhkan setiap orang percaya yang mau dekat kepada Tuhan. Iblis menggunakan berbagai cara untuk menyeret orang-orang percaya ke dalam perbuatan dosa. Oleh karena itu orang percaya harus kuat menghadapi tantangan dan godaan yang berasal dari iblis, supaya tidak jatuh ke dalam dosa.

\footnotetext{
${ }^{2}$ Tim Penyusun Kamus Umum Bahasa Indonesia, "Kudus” dalam Kamus Umum Bahasa Indonesia(Jakarta : Balai Pustaka, 1983), 532.

${ }^{3}$ W. T. Purkiser, Menggali Kekudusan Kristen, Jilid I, Dasar Alkitabiah(Yogyakarta : ANDI OFFSET, 1998), 13

${ }^{4}$ Ibid., Hal. 14.
} 

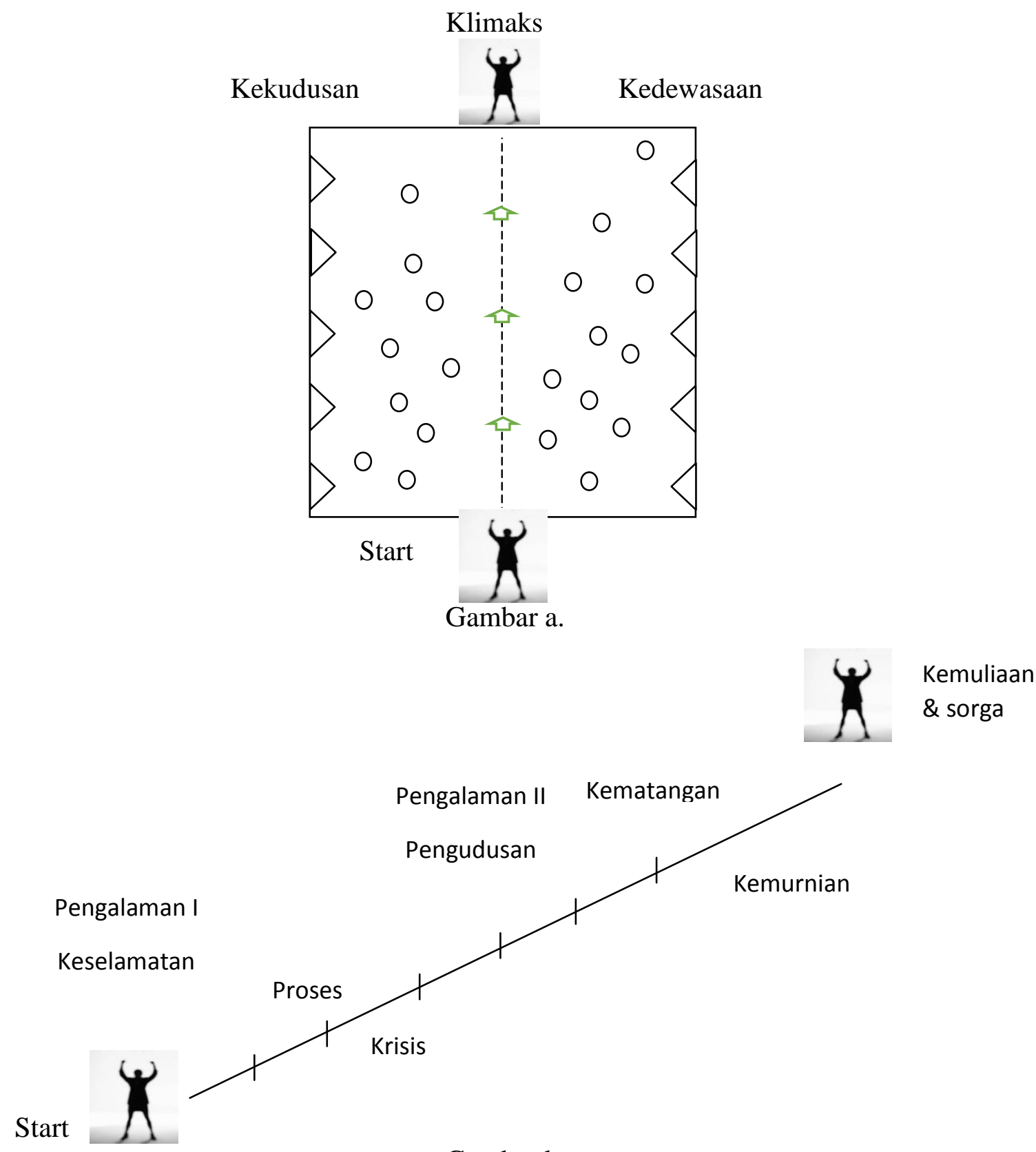

Gambar b.

Gambar (a) menjelaskan tentang kehidupan orang percaya pada saat memulai kehidupan barunya (start). Setelah mengalami pertobatan lalu dia masuk ke dalam proses pertumbuhan iman. Pada saat dia memulai kehidupan kekristenannya ia akan diperhadapkan banyak lobang yang harus ia lewati. Lobang-lobang itu adalah godaan dan tantangan, kadang jatuh dan bangun kembali. Pada masa-masa awal menjalani kehidupan baru seseorang lebih banyak menghadapi lobang dan kerikil-kerikil dalam kehidupannya. Dan ia harus berjuang untuk melewatinya, hingga lobang-lobang itu jarang lagi ditemui. Ia sudah semakin kuat dalam rohani. Buktinya ujian demi ujian berhasil dilalui. Itu berarti dia sudah dekat kepada kedewasaan rohani. Hingga pada suatu waktu datanglah kesadaran dalam hidup seseorang untuk menyerahkan hidup sepenuhnya kepada Tuhan sehingga ia mengalami pengudusan. Setelah mengalami pengudusan dalam hidup seseorang terdapat 
apa yang disebut 'kemurnian' dan 'kematangan'yang tercermin melalui sikap dan perilaku setiap hari. ${ }^{5}$

Istilah untuk menjelaskan perjalanan pertumbuhan iman seseorang mulai ia start menjalani kehidupan baru setelah bertobat adalah 'proses'. Proses ini terjadi sebelum seseorang mengalami pengudusan. Bahkan setelah seseorang mengalami pengudusan proses itu masih berlanjut sampai jiwa berpisah dari raganya.

Pengudusan terjadi dalam hidup seseorang pada saat tertentu dan pada titik tertentu. Seseorang yang mengalami pengudusan tentu sudah melewati yang namanya 'proses' seperti pembahasan diatas. Seseorang yang sudah melewati proses dia menunjukkan sebuah kematangan dan kemurnian rohani. lobang dan kerikil dalam hidup masih ada namun tidak sebanyak proses awal. Ia tidak mudah jatuh dan tergoda lagi oleh hal-hal dosa, tetapi ia bisa menguasai diri dan dengan mudah mengatasinya.

Lalu apa ciri-ciri seseorang yang mengalami pengudusan? Yang pertama, dalam hidup seseorang itu terdapat kematangan dan kemurnian rohani. sama seperti buah yang matang yang harum baunya dan indah dilihat mata. Seperti itulah hidup seseorang yang matang yaitu memiliki buah-buah yang dapat dinikmati oleh orang-orang disekitarnya. Juga terdapat kemurnian rohani ; dia menyerahkan tubuhnya kepada Allah sebagai senjata kebenaran (Rm. 6:13), dan dia mengasihi Allah dengan sepenuh hati dan mengasihi sesama (Mat. 22:37). Kemudian hidupnya mengalami kesempurnaan kristen. Kesempurnaan kristen adalah istilah yang tidak jauh berbeda dengan yang pertama di atas. Kata disempurnakan berarti penuh atau dipenuhi sampai meluap. Artinya dia mengalami kepenuhan Allah. Kepenuhan Allah adalah kepenuhan kasih. Jadi seseorang itu dipenuhi kasih kepada Allah dan kasih kepada sesama. Hidupnya diserahkan kepada Tuhan secara total sehingga bukan dirinya lagi yang memimpin hidupnya melainkan Kristus yang memimpin hidupnya.

Apakah seseorang yang mengalami pengudusan masih bisa jatuh ke dalam dosa? Seseorang yang sudah mengalami pengalaman pengudusan tidak mudah untuk jatuh ke dalam dosa dan dia juga tidak tertarik untuk melakukan hal-hal yang tidak benar. Karena dia sudah melewati proses demi proses sampai ia dikuduskan. Kalaupun masih ada kerikilkerikil dalam kehidupannya hal itu akan mudah untuk dilalui karena ia sudah dipenuhi kasih Allah. Kasih Allah dalam hidupnya akan mendorongnya untuk menghasilkan buahbuah Roh dan melakukan apa yang benar di mata Tuhan.

\section{Konsep Dikuduskan Karena Posisi}

Ide kekudusan dalam konsep ini adalah terjadi karena sebuah sebab yang dilatarbelakangi oleh sebuah peristiwa tertentu. Kekudusan dalam hal ini terjadi sematamata karena kehendak Tuhan terhadap objek yang dikuduskan. Dalam konsep ini kekudusan manusia digolongkan dalam dua kelompok. Yang pertama, kekudusan posisi atau sering disebut kekudusan imputasi. ${ }^{6}$ Dari konsep ini ditemukan bahwa tidak menuntut kualifikasi moral tertentu. Karena dikuduskan terjadi karena keberadaan atau posisi atau jabatan. Konsep ini terjadi di perjanjian lama di mana pengertian kekudusan memiliki arti yang luas sehingga bisa dikenakan baik kepada manusia maupun kepada benda. Dalam beberapa teks yang digunakan di perjanjian lama, pemakaian kata dikuduskan memiliki arti 'dikhususkan' atau 'dipisahkan'. 'Kuduskanlah bagiku anak sulung, semua yang lahir

\footnotetext{
${ }^{5}$ Robert D. Mccroskey, Theologia Sistematis dari sudur Pandang Wesleyan-Arminian, (Yogyakarta: Kabar Kekudusan, 2004), 48.

${ }^{6}$ W. T. Purkiser, Menggali Kekudusan Kristen, Jilid I, Dasar Alkitabiah(Yogyakarta : ANDI OFFSET, 1998), 34.
} 
terdahulu dari kandungan pada orang Israel, baik pada manusia maupun pada hewan, Akulah yang empunya mereka (Kel. 13:2)." Melalui teks ini memberi pengertian bahwa dikuduskan di sini adalah mengkhususkan untuk dimiliki Allah secara khusus.

Kemudian kata ini juga sering dipakai untuk menyucikan mezbah dan benda-benda yang ada di bait suci. "Musa mengambil minyak urapan, lalu diurapinyalah kemah suci serta segala yang ada di dalamnya dan dikuduskannya semua itu (Im. 8:10)." Selain dipakai untuk benda-benda, kata dikuduskan dipakai untuk manusia, misalnya suku Lewi yang menjabat sebagai imam yang melayani di bait Allah. Para imam adalah kudus karena posisi mereka sebagai imam. Dalam konteks ini mereka dikhususkan sebagai wakil dari orangorang yang hidupnya telah ditebus dengan darah anak domba paskah. Sama seperti Harun dan anak-anaknya juga dikuduskan. Dalam konteks ini kekudusan dapat diartikan pengkhususan/pentahbisan yaitu dipisahkan supaya tidak terkena hal-hal yang najis dan kotor. Hal itu dikuduskan supaya hidup dan pelayanan mereka berkenan kepada Allah.

Dalam hal ini penulis tidak menguraikan daftar dari masing-masing atau kelompok tertentu di perjanjian lama yang kuduskan. Tetapi pada kenyataannya bahwa mereka atau kelompok tertentu dikuduskan karena tugas yang mereka jalankan. Misalnya para imam atau orang-orang yang dikuduskan karena tugas tertentu seperti Gideon atau Yefta; mereka dikuduskan tapi pada kenyataannya moral mereka kurang baik; mereka melakukan hal-hal yang jahat dan tidak berkenan di hadapan Tuhan. Jadi konsep ini tidak mementingkan kualifikasi moral. Kata 'dikhususkan atau dipisahkan' berarti diambil atau dipisahkan dari tempat semula dan dipindahkan, artinya tidak melihat standar moral yang ada dalam kehidupan mereka.

\section{Perbedaan Antara Kedua Konsep}

Setelah penulis memaparkan kedua konsep kekudusan di atas, jelas telihat perbedaan. Perbedaan-perbedaan yang sangat menonjol adalah :

Pertama, Kekudusan karena posisi, tidak menuntut standar moral sedangkan pandangan Wesleyan-Arminian menuntut standar moral. Kedua, Kekudusan karena posisi terjadi karena tugas atau jabatan seseorang atau kelompok tertentu, sedangkan kekudusan dalam pandangan Wesleyan-Arminian terjadi panggilan seseorang di hadapan Tuhan. Ketiga, Kekudusan karena posisi tidak menenkan proses atau pendewasaan rohani sedangkan pandangan Wesleyan-Arminian menekankan karya Roh Kudus, proses sampai seseorang mendapatkan kedewasaan rohani.

Konsep kekudusan yang menuntut standart moral sudah mulai sejak perjanjian lama disingkapkan, dan ketika masuk dalam perjanjian baru, hal itu semakin tampak jelas dan dominan bahwa konsep kekudusan melibatkan tentang moral, kebenaran dan kebaikan. Melalui para penulis kitab-kitab di di perjanjian baru atau menyerukan dan menekankan kepada orang percaya supaya memiliki kedewasaan rohani sampai mengalami kekudusan.

\section{Impementasinya Bagi Kehidupan Orang Percaya}

Konsep kekudusan dalam pandangan Wesleyan-Arminian mengatakan bahwa pada dasarnya kekudusan didasarkan atas kualifikasi atau standar moral tertentu. Hal tersebut dipertegas oleh teks-teks dalam perjanjian baru yang mengatakan tentang standart moral kekudusan. Seseorang dinamakan 'orang kristen' atau 'orang percaya', karena dia sudah dipanggil oleh Allah keluar dari kegelapan menuju terang yang ajaib. Orang percaya dipanggil untuk menjadi umat yang kudus. Jadi dengan begitu maka kekudusan terjadi 
karena 'panggilan'. Seseorang yang dipanggil menjadi orang percaya, memiliki posisiposisi baru yang melaluinya orang percaya memiliki tabiat baru sehingga orang percaya bisa mengalami pengudusan.

Dalam konteks perjanjian baru, penulis yakin bahwa ketika Allah memanggil umatnya sebagai umat kudus, orang percaya tidak berjalan sendiri. Allah melalui peran dan kuasa Roh Kudus menolong dan menyertai orang percaya dalam perjalanan hidupnya (Mat. 28:20 ; Rm. 8:28). Dalam pertolongan-Nya, Allah memberikan jalan kepada setiap orang percaya melalui panggilan-Nya. Dan inilah yang penulis akan paparkan berikut ini yaitu bahwa setiap orang percaya dipanggil dengan diperlengkapi dengan karunia-karunia Roh Kudus (Rm. 12:6-8 ; I Kor. 7:7). Sehingga melalui karunia-karunia yang diberikan Allah merupakan suatu jalan untuk bertumbuh dan berkenan di hadapan Tuhan. Dan melalui karunia-karunia tersebut memberikan posisi yang baru bagi orang percaya. Karunia-karunia yang diberikan menunjuk kepada posisi orang percaya di hadapan Tuhan. Sehingga melalui posisi inilah setiap orang percaya bertumbuh dan dikuduskan.

Berikut ini adalah posisi-posisi baru atau tabiat baru orang percaya yang melaluinya orang percaya bertumbuh, dewasa dalam rohani dan mengalami pengudusan:

\section{Orang Percaya Sebagai Umat Pilihan}

Menyadari posisi seseorang sebagai 'umat pilihan' tentu ini adalah hal yang sangat penting dalam kehidupan orang percaya. Juga hal ini patut disyukuri dan dinikmati. Kalau melihat apa yang terjadi di perjanjian lama bahwa bangsa Israel sebagai bangsa pilihan Allah dan bangsa yang kudus. Sekian banyak bangsa di dunia hanya bangsa Israellah yang dipilih Allah. kehendak Tuhan memilih bangsa Israel adalah untuk menjadi berkat bagi bangsa-bangsa. Dalam posisi 'menjadi berkat bagi bangsa-bangsa', berarti hal ini menyangkut tugas dan tanggung jawab. Allah menginginkan bangsa itu sebagai kaki tangan-Nya. Namun apa yang terjadi? Bangsa Israel tidak memaknai posisi mereka di hadapan Tuhan dengan benar. Mereka memaknai posisi mereka dengan banyak kesalahan. Mereka menyombongkan diri dan menyembah berhala.

Kemudian jika melihat ke dalam perjanjian baru pengertian ini semakin diperjelas. Setiap penulis surat, orang percaya sebagai umat pilihan selalu ditekankan pada awal atau akhir dari surat-surat mereka. Hal ini sangat penting bagi orang percaya menyadari posisinya di hadapan Tuhan. Menjadi seseorang dipilih berarti dipanggil dan dikhususkan untuk melakukan sebuah tugas. Tugas itu adalah menjadi umat kudus dan menjadi berkat. Seseorang dipilih harus memberitakan pekerjaan-pekerjaan yang besar (I Ptr. 2:9). ${ }^{7}$ Allah yang kudus memilih seseorang untuk mengemban sebuah tanggung jawab, maka orang yang dipilih tersebut selain menjalankan tugas juga harus berkenan kepada Allah.

Ungkapan 'yang dipilih' berarti persekutuan orang kristen dalam sifatnya sebagai umat pilihan Allah, lawan dari umat manusia yang selainnya. Gereja disebut bangsa yang dipilih (I Ptr. 2:9 bdg. 2 Yoh. 1, 13), artinya mempunyai hak istimewa untuk datang kepada Allah dan tanggung jawab untuk memuji Dia, memberitakan namaNya, dan memelihara kebenaran-Nya, yang dulu dimiliki orang Israel. Seperti dulu, pemilihan dan panggilan Allah timbul dari kasih karunia-Nya menciptakan umatumat Dia- yang sebelumnya tidak pernah ada (I Ptr. 2:10 ; Rm. 9:25). Dalam kitabkitab Injil Sinoptik Yesus menyinggung 'eklektoi' (orang-orang yang dipilih) ketika Ia berbicara mengenai eskatologi. 'eklegomai' dipakai dalam kitab-kitab Injil ketika

${ }^{7}$ W.R.F. Brouwning. Kamus Alkitab, A Dictionary of the Bible, Panduan Dasar ke Dalam Kitabkitab, Tema, Tempat, Tokoh, dan Istilah Alkitabiah(Jakarta : BPK Gunung Mulia, 2001), 304. 
Yesus memilih murid-murid-Nya (Luk. 6:13; bdg. Kis. 1:24). Dan ketika gereja memilih para diaken (Kis. 6:5) dan para utusan (Kis. 15:22, 25). Inilah pemilihan untuk pelayanan khusus dari lapisan masyarakat persekutuan yang dipilih. ${ }^{8}$

Yudas (penulis surat) memakai kata 'dipanggil' dalam suratnya untuk posisi orang percaya. Berarti menunjukkan bahwa orang percaya sedang berada dalam posisi baru dan telah meninggalkan posisi yang lama. Posisi baru itu adalah sebagai umat yang ditebus dengan darah yang kudus.

Panggilan itu ialah tuntutan dikenal sebagai Kristen (I Ptr. 4:16; Yak. 2:7; Kis. 5:41; Mat. 28:19) dan untuk menjadi milik Allah di dalam Kristus (I Ptr. 2:9). 'memanggil' Mrk 2:17, ump, dan 'menamai' Luk. 1:59. Sering kata 'bernama' dipakai di dalam Luk. 7:11. Yesus memanggil murid-murid dan mereka mengikutiNya (Mrk. 1:20). Surat-surat khususnya surat-surat Paulus, menjelaskan arti teologis dari panggilan Kristus itu. Panggilan tersebut datang dari Allah, melalui kabar baik keselamatan dan pengudusan serta iman (2 Tes. 2:13) untuk masuk ke dalam kerajaan Allah (I Tes. 2:12), bagi persekutuan ( I Kor. 1:9), dan pelayanan (Gal. 1:15). ${ }^{9}$

Menjadi umat yang dipilih Allah berarti harus disertai dengan kesadaran dan tanggung jawab penuh. Orang percaya harus menyadari setiap waktu akan posisinya di hadapan Tuhan sehingga ketika ia mengingat posisinya, maka tidak mudah untuk jatuh ke dalam kejahatan dan dosa.

\section{Sebagai Hamba Tuhan}

Pemakaian istilah ini dapat dibagi dalam dua kelompok : Pertama, ditujukan kepada semua orang percaya. Dalam I Ptr. 2:11-19, rasul Petrus secara khusus menasehatkan bahwa semua orang percaya, harus hidup sebagai hamba Allah. Kata terkenal yang dipakai untuk menunjuk kepada hamba Allah ialah 'doulos'. Untuk mendapatkan makna yang lebih dari kata ini sering di samakan dalam penggunaannya dengan istilah 'budak' di perjanjian lama. Seorang budak di perjanjian lama adalah seorang yang tidak mempunyai hak apapun dalam hidupnya. Keseluruhan hidupnya tergantung kepada majikannya. Seorang budak di perjanjian lama dibeli oleh majikan dan majikan berkuasa secara penuh kepada budak yang dibeli tersebut.

Demikian gambaran orang percaya di hadapan Allah. Orang percaya adalah hamba Tuhan yang telah dibeli dengan lunas dengan tebusan darah yang mahal. Hidup yang diserahkan penuh kepada Tuhan dan mengabdi penuh kepada-Nya. Pengertian ini semakin jelas ketika rasul Paulus menjelaskan identitas dirinya sebagai hamba Tuhan (Rm. 1:1). Dia dipilih Allah sebagai hamba-Nya dan kemudian Paulus mengabdikan hidupnya untuk melayani Tuhan. Kehidupan para rasul di perjanjian baru menjadi teladan bagi orang percaya yang di pandang Allah sebagai hamba-hamba-Nya.

Kedua, adalah mereka yang punya jabatan khusus. Setiap orang diperlengkapi dengan berbagai karunia-karunia, tetapi yang penulis tekankan di sini adalah mereka yang diberi karunia atau jabatan khusus. Dalam Ef. 4:11-12, di sana tertera lima jabatan khusus yang diberikan Tuhan yaitu rasul, nabi, penginjil, gembala dan pengajar. Mereka adalah

${ }^{8}$ J.I Packer, "Pilih" dalamEnsiklopedi Alkitab Masa Kini, pen. M.H. Simanungkalit, peny. H.A. Oppusunggu, Jilid II, M-Z(Jakarta: Yayasan Komunikasi Bina Kasih, 1995), 267-268.

${ }^{9}$ Ibid, 198-199. 
orang-orang yang secara khusus dipakai Allah untuk menyampaikan kebenaran atau kabar baik. Mereka adalah orang-orang yang mengerti kebenaran maka kepada mereka dituntut tanggung jawab yang lebih besar. Seorang guru akan dihakimi menurut ukuran yang lebih berat (Yak. 3:1). Hal ini menunjukkan bahwa kepada mereka baik yang diberi karunia umum maupun karunia/jabatan khusus harus memiliki standar moral yang tinggi. Setiap mereka harus menyadari posisi mereka di hadapan Tuhan. Karena melalui karunia-karuni itu orang percaya diperlengkapi dan bertumbuh terus-menerus sampai mengalami pengalaman pengudusan. Ide yang penulis sampaikan dalam pembahasan ini ialah bahwa kekudusan karena posisi seperti ini bisa terjadi melalui karunia-karunia yang diberikan kepada orang percaya dan terutama kepada mereka yang memiliki karunia/jabatan khusus.

\section{Sebagai Murid Yesus}

Penggunaan kata 'murid' dalam Injil-injil biasanya ditujukan kepada kedua belas murid Yesus. Murid-murid itu dipanggil Yesus berdasarkan supremasi-Nya. Murid-murid itu dipanggil secara unik karena Yesus mencari dan memilih mereka. Murid-murid itu meresponi panggilan Yesus yang di dasarkan pada sebuah komitmen yang tinggi. Komitmen untuk belajar tentang firman dan mengikut Yesus dengan setia.

Yesus memilih murid-murid-Nya bukan tanpa tujuan, melainkan dengan misi-Nya yang jelas Ia nyatakan kepada murid-murid-Nya. Bahwa Yesus menyatakan misi-Nya di dunia melalui mereka, sehingga kemudian murid-murid itu disebut rasul. Jadi murid-murid Yesus dipanggil untuk sebuah tujuan dan tugas dan tanggung jawab. Hal ini semakin jelas ketika Matius (Mat. 3:14) mencatat : "Ia menetapkan dua belas orang untuk menyertai Dia dan untuk diutus-Nya memberitakan Injil dan diberi-Nya kuasa untuk mengusir setan." Kemudian Matius menambahkan catatannya ketika Yesus mengutus kedua belas murid itu (Mat. 6:7; Luk. 9:1-16). Kedua teks tersebut menjelaskan tugas seorang murid yaitu menyertai dan mengikuti Yesus dan diutus untuk memberitakan Injil. Selain itu Yesus juga menjanjikan memberi 'kuasa' kepada mereka. Tugas seorang murid disampaikan oleh Matius yang dikenal sebagai 'The Great Commision' atau amanat agung Yesus (Mat. 28:18-20). Dengan memberikan janji bahwa Yesus akan memberikan kuasa dan penyertaan kepada mereka.

Menjadi murid Yesus tidak hanya diberi tugas dan tanggung jawab. Tetapi harus menanggung sebuah konsekuensi. Konsekuensi menjadi murid Yesus adalah Yesus mengatakan kepada mereka bahwa mereka akan dibenci, keluarga mereka dibenci bahkan dunia membenci dan menolak mereka. Sama seperti halnya Yesus dibenci, ditolak dan dianiaya. Dan Yesus menambahkan penjelasan-Nya bahwa kedatangan-Nya membawa perpecahan keluarga (Mat. 10:34-36). Meskipun demikian, menjadi murid Yesus diberikan sebuah janji yaitu apabila murid-murid setia dan taat, Yesus mengatakan bahwa kepada mereka diberikan hidup yang kekal dan nama mereka terdaftar di kerajaan sorga (Luk. 10:12). Dan juga disebutkan di teks amanat agung, Yesus menjanjikan kuasa dan penyertaan-Nya sampai kepada akhir zaman. Banyak orang mengatakan bahwa untuk menjadi murid/pengikut Yesus bukan sebuah hal yang enak dan mudah. Tetapi perlu diingat bahwa tanggung jawab menjadi murid serta konsekuensi yang ada tidak lebih besar dari janji dan berkat yang diberikan Tuhan kepada murid-murid-Nya.

Istilah 'murid' mendapat makna yang lebih luas yaitu tidak hanya digunakan untuk dua belas murid yang disebut rasul itu, tetapi orang-orang lain juga yang selama ini mengikuti Yesus dengan setia dan mendengarkan Dia. Lukas mencatat hal ini pada waktu Yesus mengutus ketujuh puluh murid (Luk. 10:1-2). Penggunaan makna yang lebih luas ini ditegaskan oleh catatan Matius melalui amanat agung (Mat. 28:18-20). Melalui teks ini 
semakin jelas bahwa siapa di dunia ini yang di baptis dalam nama Bapa dan Anak dan Roh Kudus serta mereka yang sudah diajar di dalam firman Allah, mereka semua adalah murid Yesus.

Dalam pemahaman selanjutnya diberitakan di dalam Kisah Para Rasul 11:26, bahwa pertama kali di Antiokhia murid-murid itu disebut Kristen. Tidak lama setelah peristiwa pentakosta. Murid-murid mendapat pencurahan Roh Kudus, kemudia mereka memberitakan Injil. Ada banyak orang yang bertobat bahkan ribuan karena Injil. Semua orang yang bertobat memberi diri dibaptis dan diajar di dalam firman Tuhan. Lalu mereka tinggal di Antiokhia sebagai pusat berkumpulnya murid-murid itu. Mereka menjadi sebuah kelompok yang kemudian orang-orang menyebut mereka 'Kristen'. Mereka disebut Kristen karena mereka adalah pengikut Kristus Yesus. Selanjutnya dalam Kis. 24:5, Paulus disebut tokoh nasrani dan pengikut jalan Tuhan (Kis. 24:14).

Menjadi murid Yesus juga disebut keluarga Yesus. Dalam Luk. 8:19-21, ketika ibu Yesus dan Saudara-saudara-Nya mencari Dia. Lalu Yesus menjawab mereka dengan pertanyaan siapakah keluarga-Nya. Keluarga Yesus adalah mereka yang mendengarkan dan taat kepada Allah. menjadi keluarga Yesus berarti masuk dalam keluarga kerajaan Allah di mana Tuhan Yesus bertahta dan memerintah.

Dari uraian di atas tentang istilah 'murid' dapat diambil kesimpulan bahwa yang disebut murid Yesus adalah bukan hanya menunjuk kepada kedua belas murid atau rasul, melainkan setiap orang yang menyebut dirinya Kristen. Mereka yang dibaptis dan percaya kepada firman Allah, mengikut Yesus dan mendengarkan Dia adalah murid-murid Yesus. Jadi, menyadari bahwa setiap orang percaya adalah murid Yesus menjadi hal yang sangat penting dan dapat menolong orang percaya semakin dekat kepada Tuhan. Karena dengan mengingat posisi sebagai murid. Orang percaya akan melakukan tanggung jawabnya dan pada saat ia melakukan tanggung jawabnya ia sedang berada di jalan yang mendekatkan dirinya kepada Tuhan.

\section{Sebagai Anak-anak Allah}

Ini adalah hak istimewa bagi setiap orang percaya. Orang percaya bisa memanggil Allah dengan sebutan Bapa. Dalam doa yang diajarkan Yesus kepada para murid : 'Bapa kami yang di sorga......' jadi dalam doa atau nyanyian, orang percaya bisa menyebut Allah sebagai bapa (Mat. 5:45, 6:4, 6 ; Luk. 3:36 ; I Ptr. 1:17). Yesus memanggil Allah sebagai Bapa (Mat. 12:50 ; 10:32 ; Mrk. 14:36 ; Luk. 2:49 ; Yoh. 5:17, dst). Dan Allah menyatakan Yesus sebagai Anak-Nya (Luk. 1:22 ; Yoh. 3:16). Allah disebut sebagai Bapa karena sifat yang Ia miliki yaitu pengasih dan penyayang (Yoh. 5:20).

Setiap orang tua di dunia mengasihi anak-anaknya. Tetapi kasih Bapa lebih besar dari orang tua manapun. Dia merelakan nyawa-Nya supaya setiap orang yang percaya kepada-Nya memperoleh hidup yang kekal. Dia memelihara umat-Nya (providensia Allah), dan juga mendidik dan menegur (Ams. 3:11; I Kor. 11:32; ibr. 12:5). Sebagai anak-anak dari Bapa, orang percaya dinasehati untuk taat dan mengikuti kehendak Bapa. Sebagai anak-anak dari Bapa dinasehati untuk tidak mengecewakan-Nya. Posisi sebagai anak-anak Bapa diangkat menjadi pewaris kerajaan-Nya (Bil. 36:8; Maz. 25:13; I Ptr. 3:7). Ini adalah hak istimewa bagi orang percaya. Sebagai pewaris kerajaan Allah, orang percaya dinasehati untuk menghormati Allah dan tetap menjaga hubungan dengan Allah. Orang percaya harus menjaga warisan yang diberikan Allah untuk menjadi milik yang dipertahankan, bertekun di dalamnya sampai Sang pemberi warisan datang kembali. 


\section{Sebagai Tubuh Kristus}

Semua orang percaya adalah tubuh Kristus dan setiap orang percaya adalah anggota-anggotanya (I Kor. 12:27). Setiap anggota diberi karunia untuk memperlengkapi pekerjaan Allah di bumi. Setiap anggota berasal dari satu tubuh dan satu Roh. Jadi tidak dapat dipisah-pisahkan; yang satu diberi karunia ini dan yang lain diberi karunia itu. Jadi setiap anggota mempunyai tugas dan fungsi sesuai dengan karunia yang diberikan Tuhan. Tuhan memberikan karunia sesuai dengan kehendak-Nya, supaya masing-masing menjalankan fungsinya sekaligus bertumbuh di dalamnya. Sebagai tubuh Kristus tidak boleh ada perpecahan dan noda. Orang percaya harus menjaga tubuh Kristus dalam kesucian. Dan pada akhirnya Tuhanlah yang akan menilai siapa yang menjalankan tugasnya dengan baik. Sehingga Tuhan berkata : "Hai hambaku yang baik dan setia, engkau telah setia memikul tanggung jawab dalam perkara yang kecil, Aku akan memberikan kepadamu tanggung jawab yang besar, masuklah dan turutlah dalam kebahagiaan tuanmu (Mat. 25:23)."

\section{Sebagai Garam dan Terang Dunia}

Setiap orang percaya adalah garam dan terang dunia (Mat. 5:13-16). Sama seperti sifat garam yang mengasinkan, demikian juga hidup orang percaya, menggarami dunia dan membawa perubahan melalui sikap dan perilaku setiap hari. Menggarami berarti aktif dan bergerak untuk menjalankan fungsinya. Kemudian, sebagai terang berarti menjadi pelita dalam kegelapan, menuntun dan membawa orang kepada sumber terang yaitu Yesus. Sebuah cahaya lampu akan mengeluarkan cahaya apabila sudah diisi dengan minyak, sebuah lilin akan bercahaya bila ada sumbunya, dan juga senter yang harus diisi dengan baterai. Demikian juga hidup orang percaya : hidup seseorang yang masih tergoda dengan dunia, terangnya akan menjadi remang-remang dan dan kalau tidak segera memperbaiki diri maka lama kelamaan terangnya akan padam. Tetapi bagi orang yang benar, akan bersinar seperti pelita, lampu atau senter. Mampu menerangi sekelilingnya dan Tuhan dimuliakan atas hidupnya.

Sebuah buku yang penulis baca yang membahas tentang hidup orang kristen yang membawa terang, untuk istilah ini penulis buku tersebut menggunakan istilah 'orang Kristen yang menular'. Salah satu sub judulnya berbicara mengenai upah bagi orang kristen yang menular adalah ada petualangan, hubungan yang dekat dengan Tuhan, pertumbuhan rohani, keyakinan rohani dan investasi kekal. ${ }^{10}$

\section{Kesimpulan}

Penekanan kekudusan dalam pandangan Wesleyan-Arminian sangat sesuai dengan apa yang ditekankan oleh perjanjian baru tentang kekudusan. Kekudusan terjadi karena seseorang telah bertobat, menjadi orang percaya, bertumbuh dalam proses dan menjadi matang dalam rohani dan menjadi kudus. Kekudusan dalam pandangan WesleyanArminian tidak sama dengan kekudusan karena posisi. Karena kekudusan didasarkan atas standar-standar moral.

Kekudusan hidup adalah standar yang harus dimiliki dan menjadi pedoman utama dalam kehidupan. Untuk menjadi kudus memang tidaklah mudah, harus ada usaha. Penulis

\footnotetext{
${ }^{10}$ Bill, Hybels \& Mark Mittleberg, Menjadi orang Kristen Yang Menular (Yogyakarta: Yayasan Yayasan ANDI, 2000), 33.
} 
Ibrani berkata: kejarlah kekudusan. Mengejar kekudusan adalah tanggung jawab setiap orang percaya (Ibr. 12:14). Ada usaha untuk meninggalkan dosa,menyalibkan diri dan mendekat kepada Tuhan.

Meskipun demikian karena kasih Allah, orang percaya tidak berjalan sendiri. Allah melalui peranan Roh Kudus memperlengkapi umat-Nya dengan karunia-karunia yang diberikan-Nya. Sehingga untuk mencapai kekudusan menjadi dekat kepada hidup orang percaya, asalkan disertai dengan komitmen yang tingi. Inilah sarana yang memungkinkan seseorang menjadi dekat kepada Allah. melalui karunia-karunia tersebut memberikan sebuah posisi baru atau tabiat baru kepada orang percaya. Dengan menyadari posisinya tersebut di hadapan Allah, akan meminimalkan kesempatan untuk jatuh ke dalam dosa dan jauh dari Tuhan. Semakin menyadari posisinya maka ia semakin giat melakukan tugas dan tanggung jawabnya kepada Tuhan. Dan dengan itu akan membawanya semakin dekat kepada Allah. 


\section{DAFTAR PUSTAKA}

Brouwning, W.R.F. Kamus Alkitab, A Dictionary of The Bibele, Panduan Dasar ke Dalam Kitab-kitab, Tema, Tempat, Tokoh, dan Istilah Alkitabiah. Jakarta : BPK Gunung Mulia, 2011.

Fitkin, S.N. Holiness And Missions. Kansas City : Nazarene Publishing House, 1940.

Fisher, C. William. Why I am A Nazarene, and Not a Mormon, Roman Catholic, Jehova's Wirness, Christian Scientist, Seventh-Day Adventist. Kansas City : Nazarene Publishing House, 1958.

Grider, J. Kenneth. A Wesleyan-Holiness Theology. Kansas City : Beacon Hill Press of Kansas City, 1994.

Hybels, Bill \& Mark Mittleberg. Menjadi Orang Kristen Yang Menular. Yogyakarta : Yayasan Joy dan Yayasan ANDI Yogyakarta, 2000.

$\mathrm{M}^{\mathrm{c} C}$ roskey, Robert D. Theologia Sistematis Dari Sudut Pandang Wesley - Arminian, Penuntun Bagi Gembala Sidang dan Kaum Awam. Yogyakarta : Kabar Kekudusan, 2004.

Parker, J. I. Ensiklopedi Alkitab Masa Kini, Jilid II,diterjemahkan oleh M. H. Simanungkalit, disunting oleh H. A. Oppusunggu. Jakarta : Yayasan Komunikasi bina Kasih, 1995.

Purkiser, W. T. Menggali Kekudusan Kristen, Jilid I, Dasar Alkitabiah. Yogyakarta : ANDI OFFSET, 1998.

Wynkoop, Mildred Bangs. Dasar-dasar Theologia Wesleyan Arminian. 